\title{
Quality Assessment of Common Instant Noodles Sold in Nigeria Markets
}

\author{
Chukwuebuka T. Onyema*, Uche E. Ekpunobi, Augustina A. Edowube, Stanley Odinma, \\ Chinweotito E. Sokwaibe \\ Pure and Industrial Chemistry Department, Nnamdi Azikiwe University, Awka, Nigeria \\ Email: ${ }^{*}$ ct.onyema@yahoo.com, uche2004@yahoo.com, tinacalis@yahoo.com, stanleydewise@yahoo.com,
}

Received 20 September 2014; revised 5 November 2014; accepted 22 November 2014

Copyright (C) 2014 by authors and Scientific Research Publishing Inc.

This work is licensed under the Creative Commons Attribution International License (CC BY). http://creativecommons.org/licenses/by/4.0/

(c) (i) Open Access

\begin{abstract}
Proximate and heavy metal analysis of five instant noodles samples was carried out using standard analytical methods. The proximate analysis showed the presence of moisture content $\mathbf{3 . 6 5 \%}$ $7.80 \%)$, ash content $(1.11 \%-5.50 \%)$, fat content $(13.64 \%-18.69 \%)$, crude protein content $(0.167 \%-0.202 \%)$, crude fibre content $(1.00 \%-9.25 \%)$ and carbohydrate content $(63.68 \%$ 79.72\%). All essential elements (Fe and $\mathrm{Zn}$ ) investigated in the noodle samples occurred within the threshold limit of WHO, (2003) standard $(10.00-50.00 \mathrm{mg} / \mathrm{kg}$ and $5.000-22.000 \mathrm{mg} / \mathrm{kg})$ while the heavy metals ( $\mathrm{Cd}, \mathrm{Cr}, \mathrm{Mn}, \mathrm{Ni}$ and $\mathrm{Pd}$ ) in some samples occurred at levels relatively above the minimum tolerable limit of WHO, (2003). Hence, caution should be taken in the successive consumption of these noodles to avoid diseases associated with the over time accumulation of these heavy metals especially in samples where they appeared in relatively high amount.
\end{abstract}

\section{Keywords}

Proximate, Heavy Metal, Instant Noodles Analyses

\section{Introduction}

Wheat flour noodles are staple foods in many Asian countries. Historically speaking, noodles originated from Northern China and subsequently introduced to other Asian Countries by traders, seafarers and migrants. Noodles have now become more widely adopted for everyday use and its storage has been facilitated by the introduction of dried noodles. Technological innovation has also been applied to enhance noodles quality and adaptation to meet up with consumer demands and also increase the taste of boiled noodles. Instant noodles known as staple food in Malaysia lack some nutritional components such as dietary intake fibre in appropriate proportion,

\footnotetext{
${ }^{*}$ Corresponding author.
}

How to cite this paper: Onyema, C.T., Ekpunobi, U.E., Edowube, A.A., Odinma, S. and Sokwaibe, C.E. (2014) Quality Assessment of Common Instant Noodles Sold in Nigeria Markets. American Journal of Analytical Chemistry, 5, 1174-1177. 
therefore incorporation of lentil on noodles gives additional properties like increase in fibre content and indirectly contributes to protein and mineral content. Noodles are widely consumed throughout the world and their global consumption is second only to bread; it is a fast growing sector of the pasta industry. This is because instant noodles are convenient, easy to cook, low cost and have relatively long shelf-life. Wheat flour which is usually used to make instant noodles is not only low in fibre and protein content but also poor in essential amino acid; lysine. Flour of hard wheat (Tritium aestivuml) is the main primary ingredient [1] and the addition of alkaline salts can help strengthen the structure and hence improve the firmness of the final product [2]. However, contamination of food product by heavy metals is becoming an unavoidable problem these days. Air, land and water pollution are contributing to the presence of harmful elements, such as cadmium, lead, mercury and arsenic in food stuff including the instant noodles. The occurrence of heavy metals enriched ecosystem components, firstly arising from rapid industrial growth, advances in the use of chemicals for agricultural purposes and anthropogenic activities. These agents have led to metal dispersion in the environment and consequently affected the health of the population by the ingestion of victuals contaminated by harmful elements [3]. Heavy metals are regarded as toxic to living organism because of their tendency to accumulate in selected tissues. Heavy metals become toxic when they are not metabolized by the body and accumulate in the soft tissues [3]. These overtime accumulations can result in several ailments such as reduction in neuropsychological function and inhibition of biosynthesis of heme which are caused by high level of lead in the central nervous system and blood system respectively; tubular nephritis dysfunction and slight anemia caused by Cadmium in the renal system and blood system respectively; Cirrhosis and oral or nasal mucosa caused by Arsenic etc. [4].

Considering the above mentioned menace and others, efforts such as this work geared towards the determination of the dietary intake and heavy metals content of consumer foods such as instant noodles with a view to determining potential toxic agents should be encouraged.

\section{Materials and Methods-Sample Collection}

The five noodles samples were bought from Eke Awka market, Awka, Anambra State, Nigeria. The samples were as follows-Indomie instant noodles, Tummy-Tummy instant noodles, Honey well instant noodles, Dangote instant noodles and Golden penny instant noodles. All the samples were in 120 g packets.

\section{Proximate Analysis}

The proximate analysis which is the partitioning of the samples into six categories (Moisture content, Ash Content, Crude protein(kjedahl protein), Crude lipids, Crude fibre and Carbohydrates (Nitrogen free extracts)) based on their chemical properties were done using standard analytical procedures [5].

\section{Trace Metal Determination}

Using Atomic Absorption Spectrophotometer model varian AA 280, trace metal level of the samples were determined. Examined trace metals included Cd, Cr, Fe, Mn, Ni, Pd, and Zn [5].

\section{Results and Discussion}

The results of the proximate analysis of the selected noodles samples are given in Table 1 .

The relative low amount of moisture content in these noodles is in line with the common knowledge that the

Table 1. Proximate content of the selected instant noodles.

\begin{tabular}{cccccccc}
\hline $\begin{array}{c}\text { Noodle } \\
\text { Code }\end{array}$ & $\begin{array}{c}\text { Noodle's } \\
\text { Name }\end{array}$ & $\begin{array}{c}\text { Moisture } \\
\text { Content (\%) }\end{array}$ & $\begin{array}{c}\text { Ash Content } \\
\mathbf{( \% )}\end{array}$ & $\begin{array}{c}\text { Fat Content } \\
\mathbf{( \% )}\end{array}$ & $\begin{array}{c}\text { Crude Protein } \\
\mathbf{( \% )}\end{array}$ & $\begin{array}{c}\text { Crude Fibre } \\
\mathbf{( \% )}\end{array}$ & $\begin{array}{c}\text { Carbohydrate } \\
\mathbf{( \% )}\end{array}$ \\
\hline $\mathbf{V}$ & Dangote & 5.60 & 5.50 & 15.80 & 0.167 & 9.25 & 63.68 \\
$\mathbf{W}$ & Tummy-Tummy & 7.80 & 1.60 & 18.61 & 0.202 & 3.90 & 67.88 \\
$\mathbf{X}$ & Indomie & 3.65 & 1.80 & 13.64 & 0.176 & 1.00 & 79.71 \\
$\mathbf{Y}$ & Honey-Well & 6.60 & 1.50 & 18.44 & 0.211 & 3.00 & 70.30 \\
$\mathbf{Z}$ & Golden Penny & 5.15 & 1.11 & 18.69 & 0.185 & 5.85 & 69.02 \\
\hline
\end{tabular}


higher the moisture content of a food sample, the lower its shelf life because of its high susceptibility to bacterial attack. Hence, these noodles which are expected to have at least a year between date of manufacture and expiration are left with as little moisture as possible to limit rate of bacterial attack.

The Ash content of these selected noodles ranged between 1.11\% (Sample Z) to 5.50 (sample V). This showed that sample $\mathrm{V}$ (Dangote noodles) had a higher mineral content as the ash content of a food sample gives an insight into the inorganic (mineral) content of the sample.

The fat content of these samples ranged between 13.64\% (Sample X) to 18.69\% (Sample Z). The implication of this was that the sample that had more fat had more energy than the one that had less fat, however this might pose a health risk as frequent consumption of these noodles as witnessed today would lead to the development of more fatty acid in the adipose tissue and would contribute to the cholesterol level in humans with their associated health implications such as obesity and the risk of heart disease.

The low protein content $(0.167 \%-0.202 \%)$ of these noodle samples showed their deficiency in supplying adequate amount of dietary protein needed for growth and development especially in children. Therefore, caution should be taken in the over dependence on noodles or other protein sources such as egg, meat, fish etc could be incorporated while serving these noodles in other to augment this noted deficiency.

Crude fibre content of these noodles which range between $1.00 \%-9.25 \%$ on its own is perceived to be of acceptable level as crude fibres are not of definite or unique nutritive benefits but simply helped in the bowel movement. The level of crude fibre in all these samples could be seen as permissible.

The high carbohydrate content with the range of between $63.68 \%$ to $79.71 \%$ are in consonance with expected results as these noodles are usually sources of energy given the raw material for their production (wheat flour) according to Hou and Kruk, 1998 [2].

The overall observation on the heavy metal level of these selected noodles as in Table 2 showed that all the noodles fell below the WHO recommended level for essential elements (Fe and $\mathrm{Zn}$ ) hence they are not suitable to serve as a sole source for the aforementioned essential elements which may lead to deficiency of these elements in noodles consumers and their associated health effects [4] [6]. Several cases of human disease, disorders, malfunction and malformation of organs due to metal toxicity have been reported such liver cirrhosis, Tubular nephritis Dysfunction, Reduction in neuropsychological function, etc. [7]. On the other hand, the levels of heavy metals in these noodles did not follow a uniform pattern as some conformed to the WHO permissible levels for heavy metals in food samples while few others were a little beat above the permissible limits as seen in the $\mathrm{Cr}$ and Cd levels of all the samples except for Tummy-Tummy $(0.003 \mathrm{mg} / \mathrm{kg})$ and Honey-well $(0.001 \mathrm{mg} / \mathrm{kg})$ which showed total conformity to the WHO standard for $\mathrm{Cr}(0.003 \mathrm{mg} / \mathrm{kg})[8]$.

\section{Conclusion}

These little variations observed in the Proximate and most especially the Heavy metal compositions of the selected noodles samples, might not pose any immediate serious health effect given their accumulation in the human body but long time accumulation of these metals could lead to health issues.

\section{Recommendation}

It is therefore recommended that manufacturers of these noodles review the sources of these heavy metals which

Table 2. Results of the Heavy metal analysis of the selected noodles samples.

\begin{tabular}{cccccccccc}
\hline $\begin{array}{c}\text { Noodle } \\
\text { Code }\end{array}$ & $\begin{array}{c}\text { Noodle's } \\
\text { Name }\end{array}$ & $\begin{array}{c}\mathbf{C r} \\
(\mathbf{m g} / \mathbf{k g})\end{array}$ & $\begin{array}{c}\mathbf{C d} \\
(\mathbf{m g} / \mathbf{k g})\end{array}$ & $\begin{array}{c}\mathbf{F e} \\
(\mathbf{m g} / \mathbf{k g})\end{array}$ & $\begin{array}{c}\mathbf{M n} \\
(\mathbf{m g} / \mathbf{k g})\end{array}$ & $\begin{array}{c}\mathbf{N i} \\
(\mathbf{m g} / \mathbf{k g})\end{array}$ & $\begin{array}{c}\mathbf{P b} \\
(\mathbf{m g} / \mathbf{k g})\end{array}$ & $\begin{array}{c}\mathbf{Z n} \\
(\mathbf{m g} / \mathbf{k g})\end{array}$ \\
\hline $\mathbf{V}$ & Dangote & 0.063 & 0.005 & 1.625 & 0.135 & 0.010 & 0.029 & 1.797 \\
$\mathbf{W}$ & Tummy-Tummy & 0.084 & 0.003 & 3.086 & 0.157 & 0.028 & 0.064 & 1.358 \\
$\mathbf{X}$ & Indomie & 0.097 & 0.005 & 1.343 & 0.115 & 0.013 & 0.026 & 1.482 \\
$\mathbf{Y}$ & Honey-Well & 0.079 & 0.001 & 1.079 & 0.112 & 0.007 & 0.025 & 0.359 \\
$\mathbf{Z}$ & Golden Penny & 0.118 & 0.008 & 1.550 & 0.097 & 0.004 & 0.106 & 0.973 \\
& WHO Standard & 0.050 & 0.003 & $10.000-50.000$ & NA & NA & 0.025 & $5.000-22.000$ \\
\hline
\end{tabular}

NA = not available 
could be from the water they use or their machineries with a view to reducing them further to permissible levels. The protein content of these noodles should also be improved in order to be able to fairly supply the required daily allowance.

\section{References}

[1] Fu, B.X. (2008) History, Classification, Raw materials and Processing. Food Research International, 41, 888-890. http://dx.doi.org/10.1016/j.foodres.2007.11.007

[2] Hou, G. and Kruk, M. (1998) Asian Noodle Technology. Technical Bulletin 20:10. International Food Research Journal, 19, 309-313.

[3] Zukowska, J. and Biziuk, M. (2008) Methodological Evaluation of Method for Dietary Heavy metal intake. Journal of Food Science, 73, R21-R29. http://dx.doi.org/10.1111/j.1750-3841.2007.00648.x

[4] Igwe, J.C, Ihesilo, P.O. and Nnorom, I.C. (2012) Trace Element Analysis of Forage Samples in Niger Delta of Nigeria. Journal Chemical Society of Nigeria, 37, 93-97.

[5] AOAC (1998) Official Method of Analysis. 15th Edition, Association of Official Analytical Chemists, Washington DC.

[6] Prasad, A. (1976) Deficiency of Zinc in Man and Its Toxicity. In: Prasad, A.S. and Oberleas, D., Eds., The Nutrition Foundation, Trace Elements in Human Health and Diseases in Zinc and Copper, Academic Press, New York, Vol. 1, $1-20$.

[7] Jarup, L. (2003) Hazards of Heavy Metal Contamination. British Medical Bulletin, 68, 167-182. http://dx.doi.org/10.1093/bmb/ldg032

[8] WHO (2003) World Health Organization Provisional Tolerable Weekly Intake of Toxic Heavy Metals. 
Scientific Research Publishing (SCIRP) is one of the largest Open Access journal publishers. It is currently publishing more than 200 open access, online, peer-reviewed journals covering a wide range of academic disciplines. SCIRP serves the worldwide academic communities and contributes to the progress and application of science with its publication.

Other selected journals from SCIRP are listed as below. Submit your manuscript to us via either submit@scirp.org or Online Submission Portal.
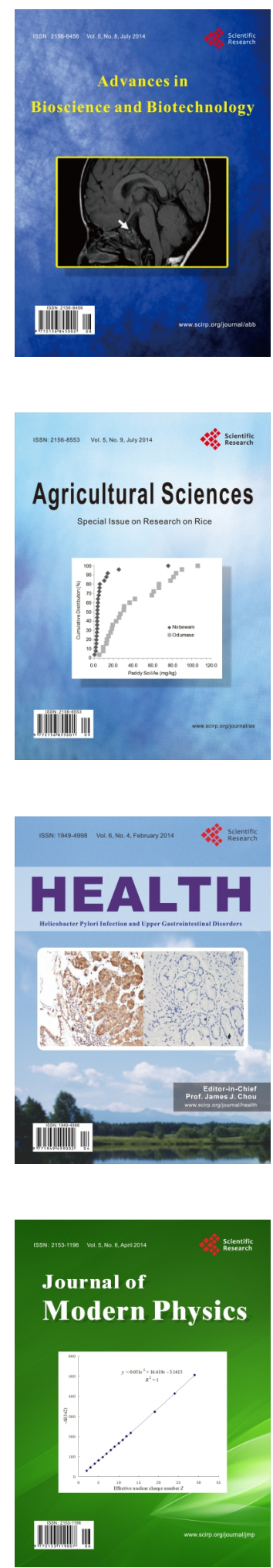
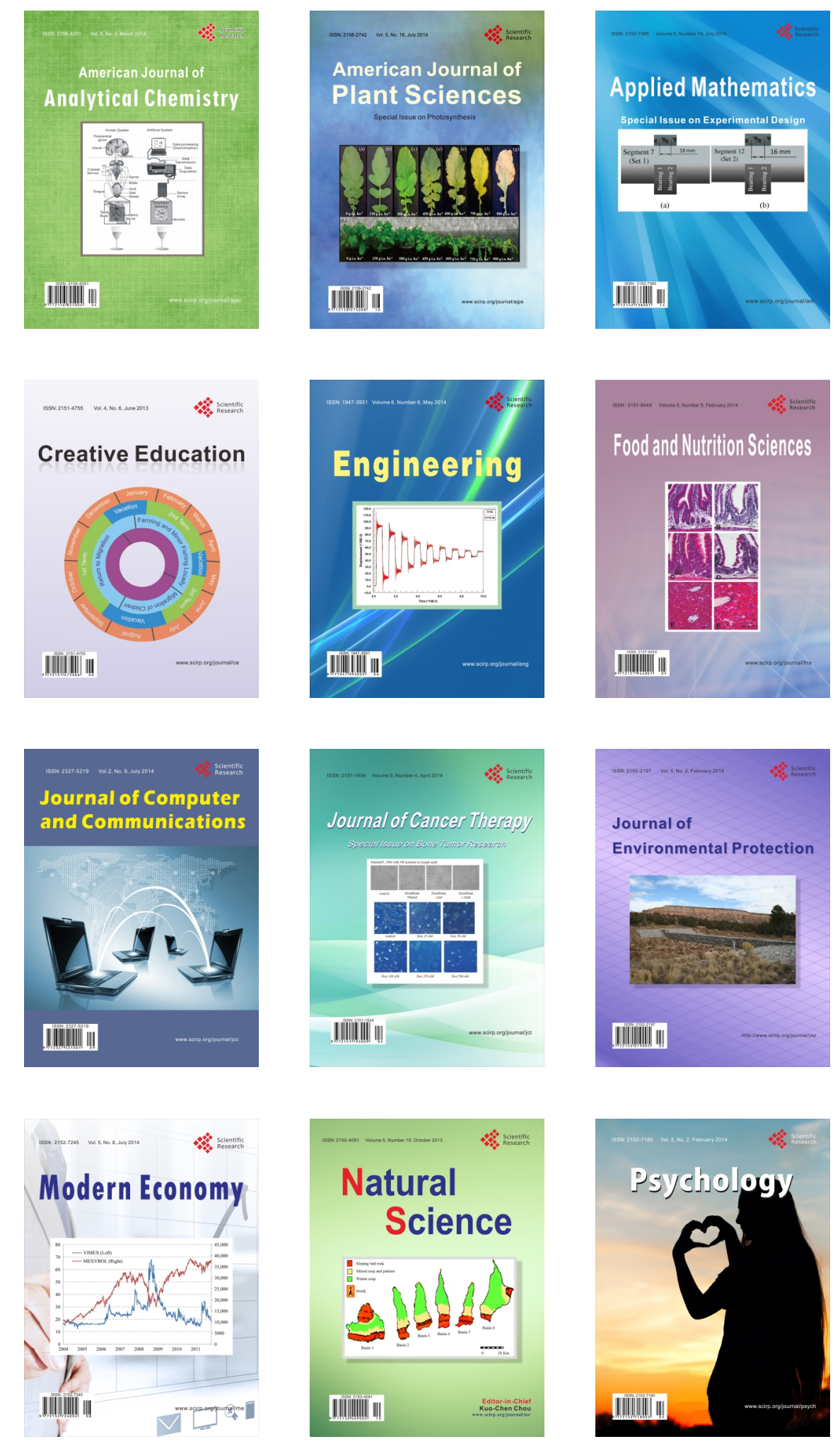